\title{
TWO-SPIRITS AND THE DECOLONIZATION OF GENDER
}

\author{
Bayu Kristianto
}

\begin{abstract}
Abstrak
Masyarakat pribumi di Amerika dan di bagian dunia yang lain menolak pendapat para teoretisi poskolonial bahwa kolonialisme telah berlalu meski efeknya masih dirasakan sampai sekarang. Bagi mereka, kolonialisme masih berjaya dan tetap mencengkeram kehidupan masyarakat pribumi yang hidup di tengah masyakat asing dominan di tanah milik mereka. Usaha-usaha menuju dekolonisasi telah dilakukan dari dulu sampai sekarang, dan bentuknya semakin beragam seiring berjalannya waktu. Makalah ini bermaksud menunjukkan bahwa usaha menuju dekolonisasi telah dilaksanakan oleh masyarakat pribumi Amerika semenjak proses kolonisasi dimulai. Analisa dipusatkan pada figur Two-Spirit, We'wha yakni figur individu pribumi yang memiliki identitas gender ganda. Bahwa masyarakat penjajah hanya mengakui adanya dua identitas gender merupakan suatu bentuk penjajahan yang senantiasa mendapat perlawanan dari masyarakat pribumi. Dengan demikian, usaha untuk menonjolkan gender alternatif merupakan suatu bentuk dekolonisasi yang signifikan karena binari gender merupakan bagian integral dari ilmu pengetahuan dan filsafat barat. Figur We'wha, tokoh TwoSpirit terkenal dari suku Zuni, membawa gender alternatif ini tepat ke tengah-tengah masyarakat elit Washington D.C. yang berpegang teguh pada oposisi gender yang ketat. Dengan menonjolkan perpaduan kualitas pria dan wanita dalam satu individu, We'wha menciptakan krisis epistemologi yang tidak bisa dipahami oleh masyarakat dominan Amerika. Hal ini membuktikan bahwa masyarakat pribumi Amerika telah terlibat dalam proses dekolonisasi dalam berbagai bentuk, baik fisik, psikologis, maupun kognitif.
\end{abstract}

\section{Kata kunci}

Poskolonialis, dekolonisasi, negara-negara yang dijajah, negara-negara penjajah, menentukan nasib sendiri, kebijakan-kebijakan rekonsiliasi, tokoh pria-wanita Zuni, We'wha.

\section{INTRODUCTION}

Post-colonialists contend that political decolonization happened when colonized countries gained their independence in the 1950s to 1970s; however, cultural decolonization, or the decolonization of the mind, is a more arduous process than the formal and legal process of decolonization. The Western ways of knowing the world have been so ingrained in the minds of the colonized people that the process of reversing this condition has become much more difficult than the physical decolonization (Sharp 5). In the area of research in our current era, governments of settler nations have attempted to address the issue of decolonization through designing and applying self-determination 
and reconciliation policies, but the research community has not considered decolonization agenda as occupying the top priorities. History has taught us that botanists, medical scientists, and anthropologists conducted research on the assumption of cultural superiority. The objectivity of scientific research, which tended to benefit the dominant society, regarded indigenous people as mere objects of research and never addressed their needs (Prior 163). These facts inform us of the continued need of decolonization process both at present and in the future as native people still grapple with the ongoing pressures of colonialism in their communities.

In this paper, I argue that the ways toward cultural decolonization can be found both in the contemporary periods and in the past historical settings. I contend that decolonization does not only belong to indigenous people living in the postcolonial world; rather, I argue that indigenous people in the past were already engaged in the process of decolonization, often in ways that were uniquely intriguing within their own cultural and historical contexts. I focus my analysis on the figure of the Zuni Two-Spirit person, We'wha, who actively involved himself in the decolonization struggle against American colonialism, curiously utilizing his man-woman status, a category highly respected by the Zuni community but severely despised by the dominant white society. I argue that We'wha was able to carry out the attempts at decolonization by encountering the dominant white perspective regarding indigeneity and gender identity, and in so doing he demonstrated native and Two-Spirit people's capability to counter epistemological and gender colonialism so prevalent among indigenous communities struggling with internal colonization in their land.

\section{DECOLONIZATION ANDTHE GENDER QUESTION}

It seems clear that cultural decolonization is a much more pressing issue than physical and political decolonization. Even though a number of indigenous people object to postcolonialism's rendering of colonialism, emphasizing the fact that colonizers have not left the colonized land, the decolonization of the mind has become the center of our academic and philosophical engagement. Linda T. Smith argues that scientific methodologies and methods of research need to be decolonized. In her view, decolonization does not refer to the "total rejection of all theory or research or Western knowledge" (Smith 37). Decolonization is more related to the "centering [of] our concerns and world views," focusing on comprehending theory and research from indigenous views to achieve the objectives of indigenous people's struggle (Smith 37).

There is a crucial need to decolonize the academic world because of its persistent assumption of native subjects as the Other that had to be objectified. The process of objectification itself is a manifestation of dehumanization. Thus, indigenous communities are struggling against an immense power since science as regime of truth, following Foucault's contention, is still dominated by the notion of superiority of Western 
epistemology. Without decolonization, objectification will continue and indigenous people will still be relegated to an inferior, subhuman, or even non-human status. This is the reason why cultural and scientific decolonization is a highly crucial issue in indigenous studies and among indigenous communities.

Vine Deloria points out that Western science was established on a deep-seated mythology which its proponents refused to forsake. There is a need for an alternative way of thinking that can decolonize our mind from epistemological colonization of Western science. Deloria supports Feyerabend for seeing the need to "demythologize" certain principles that limit our ability to comprehend reality holistically (Deloria 4). Feyerabend realizes the need to accept alternative ways of knowing and thus is flexible in accepting new data and integrate non-Western forms of knowledge into the scientific framework (Deloria 12). Deloria proposes that there is a need to return to the tribal epistemology of American Indian people in North America, which possesses intriguing, and possibly out of the ordinary but at the same time valid, ways to understand reality

In addition to the need for epistemological decolonization, and in a close relation to it, the issue of colonialism of gender is not less important since the Western world clings to the rigid separation of two genders and rejects alternative gender identities. Indigenous communities who accepted and benefited from the presence of Two-Spirit people, or berdaches (a Western anthropological term, less preferred than Two-Spirit) were under attack by colonial government bodies for harboring the existence of Two-Spirit people. In line with Christianity's assault on native belief-systems, members and governments of settler societies maintained that the presence of Two-Spirits was the manifestation of religious corruptness of indigenous people, constantly encouraging feelings of profound disgust among the dominant society. However, the persistent presence of Two-Spirit people is in essence a demonstration of indigenous people's resilience against colonialism. The fact that native communities continue to integrate Two-Spirits into their lives implies that the colonial project of subjugating recalcitrant gender identity has only resulted in constant failure.

Julia V. Emberley, in her book Defamiliarizing the Aboriginal, Cultural Practices and Decolonization in Canada, holds that a social critique of homophobia is "a strategy of decolonizing the multiple and complex forms of colonial violence and brutality" (256). Analyzing Shelley Niro's film Honey Moccasin, she observes that the film employs the figure of the berdache (indigenous male homosexuality) as "a site for the production of the distinction between modernity and 'savagery' or traditionalism" (256). Thus, the figure of the Two-Spirit plays a crucial role in the process of gender decolonization as it violates Western epistemology and religious framework with regard to accepted gender identities. The insistence on two genders and the rejection of alternative genders is a prominent part of the colonization project that needs to be overturned. Therefore, the Two-Spirit's actions vis-à-vis colonial agents' are efforts of decolonization and the 
endeavor for employing indigenous epistemology in the issue of gender and sexuality, following Deloria's suggestion on the return to tribal epistemology.

On the importance of transgender figure in the process of decolonization, Emberley contends that transgendering enacts the activity of "crossing" manifold boundaries that is crucial in decolonization:

Of course, transgendering is about gender and sexual identity, but it is also about crossing multiple zones of desirability and commodification: crossing borders between the spectacle and the commodity, between the technologically produced image and the materialities of economic and political power, between the public and private negotiations of identity, sexuality, love, and labour (Emberley 257).

There is a significant emphasis on the ability of Two-Spirit people to negotiate with different areas of identity, sexuality, love, and labor. The ability to "cross borders" signifies the important role that Two-Spirit people play in disrupting the hegemony of gender binarism, which also corresponds to the binary notions within colonialism, e.g. civilized vs. uncivilized, white vs. non-white, science vs. superstition, and Christianity vs. paganism. Marjorie Garber, quoted by Emberlye, maintains that the presence of transvestite in a text "indicates a category crisis elsewhere, an irresolvable conflict or epistemological crux that destabilizes comfortable binary, and displaces the resulting discomfort onto a figure that already inhabits, indeed incarnates, the margin" (Emberley 257, emphasis in original).

Thus, the role of Two-Spirit people in historical and literary texts should be the object of significant scholarly engagement as they were capable of dislocating colonial binarism from its convenient base. Emberley asserts that the transgender figures "do not only constitute a response to ideological forces of containment, but actively go beyond such forces by signaling the necessity for transformation and change" (Emberley 258). Therefore, the Two-Spirit people's power to create "a semiotic rupture with the 'Real' [i.e. the accepted binarism as a foundational element of colonial mindset]" needs to be highlighted in cultural analyses of decolonization (Emberley 258).

\section{TWO-SPIRIT PEOPLE AND DECOLONIZATION}

The Zuni people are known as sedentary agricultural people. For long periods of time, the Zunis have cultivated corn, squash, and beans, which were tended traditionally by men. Interestingly, men also took part in cotton weaving using looms, and the Zunis had been known for having cotton fields since the Spaniards arrived in the area (Hultkrantz 115). The Zunis are also a very ritualistic community. There are gods and spirits in the Zuni religion, but they are mostly hidden in ritual performance. Zuni ceremonies take place in the ceremonial chambers (kiva) and on the open plaza. Despite the existence of the Catholic church among them, the Zunis steadfastly cling to their traditional religion, as other Pueblo Indians do (Hultkrantz 116). 
The first assaults on Zuni culture were committed by the early anthropologists. These were among the first agents of colonization among the Zunis before the U.S. government literally interfered in the cultural and religious life of the people. Anthropologists were eager to find models of society to be preserved and then imitated. The actions of the anthropologists were almost as old as the taking of Indian lands and the obliteration of Indian culture. Anthropologists admired the Zunis because they saw the employment of social responsibility which was combined with individual tolerance, where there were autonomous interdependent groups responsible for particular social functions but none was so dominant as overtaking the others. However, despite their admiration at the Zuni culture, anthropologists more often strengthened the image of the vanishing Indian than challenged it. It is a legacy of both knowledge and annihilation, i.e. early anthropologists were both agents of science and the first proponents of colonization. They saw the need to rescue primitive cultures as these cultures were deemed to be on the brink of extinction. Thus, they caused the removal of religious objects from tribal possession so that certain Zuni ceremonies had to be changed or suspended. Furthermore, early anthropology only benefited the colonizers or the dominant culture rather than the indigenous people who became the objects of anthropological research.

A prominent figure within the Zuni society is the berdache, or more famously known among North American native communities as the Two-Spirit people. The Zuni term for this figure is lhamana. Will Roscoe defines the Two-Spirit person as "a man who combined the work and social roles of men and women, an artist and a priest who dressed, at least in part, in women's clothes" (Roscoe, The Zuni Man-Woman, 2). Callender and Kochems define the berdache as "a person, usually male, who was anatomically normal but assumes the dress, occupations, and behavior of the other sex to effect a change in gender status" (443). What is important to emphasize is the fact that the berdache refers to a "distinct gender status, designated by special terms rather than the words 'man' or 'woman'" (Callender and Kochems 443). Thus the designation of the berdache as simply homosexual, transvestite, and hermaphrodite is simply inappropriate as these terms connote the notion of either lack or excess which deviates from the normal. Even though native communities understand that gender is socially constructed, they view the third gender as a common part of their society.

The term 'Two-Spirit' is preferred by Indian communities because 'berdache' is a term used by anthropologists to refer to Two-Spirit people in North America. Alex Wilson points out that the term berdache "described anthropological subjects who did not fit neatly into European American gender and sex role categories, meaning a category of (gendered and sexual) 'other'" (304). Among Indians in North America, however, Two-Spirit people were never designated as the Other; in fact, they were an integral part of religious ceremonies and deeply-committed cultural preservers. In fact, Two-Spirit people possess an identity which "affirms the interrelatedness of all aspects of identity, 
including sexuality, gender, culture, community, and spirituality" (Wilson 304-305). This signifies that instead of reflecting a deviation from societal values, Two-Spirit people represent these values in a comprehensive manner through their appearance, actions, and mode of thinking. Two-Spirits express a balance of masculine and feminine qualities, or male and female spirits, which is commonly referred to as androgyny. It is the roles and responsibility unique to Two-Spirit people that are respected by North American native communities (Wilson 305).

Elsie Clews Parsons, one of the early anthropologists studying the Zuni culture, points out in her 1916 essay that regarding the presence of Two-Spirit people, "there seemed to be no reticence in general and no sense of shame" (Parsons 523). Two-Spirit people were regarded as part of the community who did not possess an abominable image of sexual corruptness as the Christian West saw it. Ruth Benedict, in her book Patterns of Culture, holds that there were different factors why a native person chose to become a TwoSpirit. However, regardless of the reason, men who opted to don a woman's dress and perform female duties had the same opportunity as other community members to take part in the functioning of the community. All their conducts were acknowledged socially by all community members (Benedict 264, qtd. in Roscoe, The Zuni Man-Woman, 27).

Roscoe explains that Two-Spirit people often, but not always, cross-dressed. In addition, they often put on a combination of men's and women's attires. As they mixed their clothing, they also combined "social, economic, and religious activities of both sexes along with responsibilities unique to berdache status" (Roscoe, "We'wha and Klah," 127). The prevalence of the Two-Spirit figure is reflected in the different names that each tribe designated for him: the Zunis call him lhamana, nadle is a Navajo term for this figure, the Crows named him bote, and the Teton Dakotas (Western Sioux) call them winkte (Roscoe, "We' wha and Klah," 127, Roscoe, "Crow Berdache," 47, Forgey, 5).

With regard to the origins of Two-Spirit persons, Zuni mythology provides a narrative concerning how the berdache came into being. Parsons describes it as follows:

[F]rom the mingling of too much seed in one kind, comes the two-fold kind, 'hIdhmon, being man and woman combined--even as from a kernel of corn with two hearts, ripens an ear that is neither one kind nor the other, but both! (Parsons 254).

Thus, we can see that the figure of lhamana is characterized by a superfluous human quality as "too much seed" was mixed in one form, resulting in a being consisting of two elements, i.e. man and woman. This origin story counters the assumption that lhamana is marked by a lack of human quality, or a weakness.

Examining decolonization through the berdache figure, let us focus on the figure of We'wha, a famous Two-Spirit person from the Zuni tribe. We'wha was born in 1849, but both of his parents died when he was only an infant, which may have been caused by the prevalence of smallpox carried by American emigrants passing the area. We'wha and his brother were raised by his aunt, and he remained a member of his mother's 
clan, donashi:kwe, or Badger People, with a spiritual connection to his father's clan, bichi:kwe, or Dogwood People (Roscoe, The Zuni Man-Woman, 31). Fascinated by religious proceedings, We'wha received religious training, which included memorization of religious songs, prayers, myths, and lore of the kachinas, at which We'wha proved to be especially competent. However, once his gender orientation became known, We' wha underwent vocational training under the direction of female relatives. We'wha's learning was focused on domestic and crafts work (Roscoe, The Zuni Man-Woman, 38). He was also skilled at maintaining cleanliness and order in the house, while also capable of reaching perfection in performing certain female chores such as fetching wood, carrying water on the head, threshing wheat, and tending waffle gardens. We'wha mastered the art of making ceramics, and he was highly skilled in weaving. He also worked as a matron at the mission school, whose responsibilities included supervising the dorms, kitchen, laundries, providing instructions in domestic work to girls, and taking care of little children. Matilda Coxe Stevenson acknowledged We'wha as "the most intelligent person in the Pueblo" (Roscoe, The Zuni Man-Woman, 46).

We'wha negotiated change by creating friendships with Anglo-Americans living among his people, and he was also interested in learning English. This attitude made him an excellent informant, which Stevenson found useful for her project. We'wha also became a competent laundryman, who used his own clean clothes on his body to advertise for this skill. Stevenson wrote that We'wha was "the strongest [Zuni] both mentally and physically, ...[having] good memory, ...[and possessing] an indomitable will and an insatiable thirst for knowledge" (Roscoe, The Zuni Man-Woman, 47). Due to all of his abilities, Stevenson decided to bring We'wha to Washington D.C. in 1882 in order that the American public could learn about Indian culture from a real Native American person. At the same time, she could attempt to secure funding for her own research.

It was in Washington that We'wha demonstrated adept skills as negotiator, playing in between the Zuni and the white American cultures. During his stay in Washington, he became the subject in numerous articles, and he was constantly occupied with a lot of social, diplomatic, and scientific activities (Roscoe, The Zuni Man-Woman, 55). We'wha's language acquisition was amazing: he quickly understood English and tried eagerly speak using the language. He was able to find his way around the city, following the streetcar tracks and taking long walks both day and night. He always showed industriousness, spending his time weaving and in one occasion making himself work capably fixing a leak on the roof. Attending receptions at the elite societies, We'wha created jealousy as the crowd flocked to meet him, leaving the most attractive ladies poignantly left out. We'wha was successful at adjusting himself to all the formalities of the life of the Washington's elite society. Out of careful observation and learning, he knew perfectly how to behave in a so-called 'civilized' society. He knew that his dress was different from that of fashionable ladies he met and managed to buy a large satin parasol on a discounted price. 
All these skills and intelligence made We'wha highly famous among the white society in Washington, which made him have to be present in numerous receptions, formal calls, meetings with national leaders, and interviews with reporters (Roscoe, The Zuni ManWoman, 55).

We'wha's intelligence that was demonstrated during his 6-month stay in Washington constitutes a strategic play of agency, which reflects native people's capability at conducting efforts of decolonization. First of all, by bringing We'wha to Washington D.C., Stevenson and the American public was engaged in a project of colonization as they were trying to define what an Indian was. An Indian was understood as barbaric, savage, unrefined, unrestrained, wild, uncivilized, and other degrading labels imposed by the dominant white society. This was their expectation when encountering the figure of We'wha, a TwoSpirit person from the Zuni tribe. Instead of fulfilling this expectation, We'wha opposed all forms of definition by the white society. He proved himself to be a highly intelligent person, well-mannered, very skillful in art, masterful of his own Zuni culture, all of which managed to impress members of the elite society. We'wha showed a high level of artistry and a deep commitment to his own culture as he was constantly following protocols. While early anthropologists showed disrespect toward Zuni protocols, We'wha was able to abide perfectly by the protocols of the Western society. We'wha proved to be a much better cultural negotiator than Western anthropologists during the era.

Encountering We'wha, the dominant white society persistently tried to define him. Regarding the West's constant need to define the Other, Linda T. Smith contends that " $[t]$ hese systems for organizing, classifying, and storing new knowledge, and for theorizing the meanings of such discoveries, constituted research. In a colonial context, however, this research was undeniably also about power and domination" (60). Thus, when the dominant society in Washington attempted to understand We'wha as an Indian, essentially they were trying to confine We'wha within a certain category which they could comprehend, which would later be used to serve their purpose, i.e. subjugating the native people in America. What seems like an invitation for We'wha to appear in social occasions was indeed the exercise of epistemological power of defining and categorizing, so prevalent in Western science and research. However, We'wha managed to counter against this imposition of the Western gaze on his Indian identity.

The dominant society failed to define him and locate him within a strict category. His status as an Indian and a Two-Spirit person enabled him to play with Western scenario of defining and dominating his multiple identities. We'wha was constantly able to create definitions and interpretations about the white society, which made him easily accepted among them and made them marvel at his intelligence. When the roof of the house was leaking, he knew that he had to climb up the house and fix it immediately. When attending elite parties, he knew perfectly how to behave so that he conformed to the etiquette that prevailed among the elite community. From learning and observation, 
he knew his way around the city and managed to buy a satin parasol on a sale. These successes demonstrate that We' wha constantly defined what he observed around him, and his interpretations proved to be working perfectly and effectively well.

Interestingly, We'wha was admired for his abilities, but at the same time he was a berdache, although the public in Washington was not aware of this pertinent fact. The West considered a berdache as an anomaly, a freak of nature, and a demon committing an abominable, unpardonable sin for the Christian god. We' wha was supposed to be hated for his gender status, but his intelligence and abilities managed to counter any definition of gender identity by the dominant society. He brought confusion with regard to his gender identity, but it did not result in repulsion. Some members of the public actually questioned whether We'wha was in fact a woman. Roscoe writes: “Of course, doubts rose [concerning his gender]. That is not surprising. What is surprising is how easily they were set aside" (The Zuni Man-Woman, 59). This statement indicates that the public kept thinking of $W e^{\prime} w h a$ as a woman despite his apparent masculine physical features, but in the end they failed to define him as a Two-Spirit person. As an intelligent agent and negotiator, we can imagine We' wha saying to the dominant public at that time: "You want me to fulfill your expectations as an Indian, so I will give you anything that you want from me." This is shown by his willingness to show his skills in traditional Indian arts, i.e. weaving, making ceramics, and dancing in public. However, we can further imagine him saying: "But you can never define me. I am beyond your colonial mindset and imperial project."

There are two sets of labels that the West would happily impose on the figure of We'wha at that time, as seen in the following:

\begin{tabular}{|l|l|}
\hline Labels of Indians & Labels of Berdache \\
\hline Savage & Demon \\
\hline Wild & Deviant \\
\hline Violent & Pervert \\
\hline Barbaric & Sinner \\
\hline Pagan & Corrupt \\
\hline Uncivilized & Male prostitute \\
\hline Unintelligent & Sodomite \\
\hline Unrestrained & Slave / kept boy \\
\hline Without art & Transvestite \\
\hline Dirty & Hermaphrodite \\
\hline Static & Sissy / coward \\
\hline
\end{tabular}


In the Western mind, all of these labels should have applied, and should have been applied, to We'wha. However, he showed that none of these labels could be applied to the figure of Two-Spirit that he represented. We' wha wanted the whole white society to see that he was against imposed colonial construction by the dominant society, which allows us to say that his visit to Washington provided him ample opportunities to perform efforts of decolonization. He wanted to show that what was despised by the Europeans, i.e. the Indian and the Two-Spirit, was in essence the opposite: he was productive, highly artistic, acutely aware of the importance of protocols, showed good manners and able to carry himself properly in all situations, and possessed authoritative self-confidence. As the West's defining indigeneity and masculinity was unsuccessful when encountering We'wha, what ensued was an epistemological crisis when the West was in limbo at this downright failure.

This epistemological crisis happened because there was nothing in the inventory of Western science which could be utilized to define both an INDIAN and a BERDACHE. With the Enlightenment, and when science was still in its early phase in the 1880's, everything had to be accurately defined from the viewpoint of science. Early anthropologists were highly motivated to define indigenous communities, to examine their culture, to produce detailed categorizations of elements of their traditions, and to create a science of the Other. After venturing to indigenous tribes, immersing themselves in the life of the people, and making close and personal observations, I believe that these anthropologists were quite capable of defining what constituted an indigenous person and indigenous culture. Also, they may have had the image of a berdache from their own cultural inventory. However, the merging of an indigenous person AND a berdache created a pressing problem for these anthropologists and the whole Euro-American society at large, including the U.S. government, with its accomplices, i.e. the Christian missionaries.

This merging is like the confluence of the worst qualities that society can find in a human being (see the table on the previous page), and the West was extremely horrified to have found such a figure among indigenous communities. Subsequent years would be spent by the U.S. government and the churches to suppress and to root out the existence of Two-Spirit figures among Native communities as they were deemed abominable from the standpoint of both Western civilization and Christianity. This suppression was the evidence that Two-Spirit persons created a category crisis, a term used by Julie V. Emberley, within the dominant Euro-American society. I argue that Wewha genuinely realized that the Euro-American society he was visiting possessed such a way of thinking in mind. Thus, he intentionally consented to Stevenson's invitation to sojourn to Washington D.C. because he was conducting a grand project of creating such an epistemological catastrophe in the Western mind. At the same time, he wanted to enlighten the West about the realities of Native American persons and traditions. All those labels applied to him by the whites crumbled violently as he proved that he was the 
total opposite of what the West had imagined.

One question may arise: was We-Wha fascinated by the Western culture that he saw? How did he make his own interpretation of what he observed to prove that he was a cultural critic of Western civilization? Will Roscoe provided one pivotal piece of evidence. He quoted Edmund Wilson, who made a visit to the Zuni tribe in the 1940s, who made a statement that We-Wha convinced his fellow Zunis that the white women were impostors, for We-Wha had found them in the ladies' rooms, pulling out their artificial teeth and the "'rats"' from their hair (Wilson, in Roscoe, Zuni Man-Woman, 71). It seems that he knew that artificiality and insincerity constituted a prominent part of the Western culture, something which he had previously learned from the behavior of anthropologists in his Zuni community. Interestingly, We-Wha came to Washington D.C. in 1882 , but it took more than 40 years for the Washington society to realize that WeWha had actually been making fun of them with his visit. A newsletter published by the Indian Rights Association, written by Clara True, mentioned in 1924 that:

The gullibility and unreliability of some scientists ... is illustrated in the amusing incident of "We-Wha," the Zuni Indian who passed, during several years spent in the service of some eminent representatives of the Bureau of American Ethnology, for a wonderfully intelligent Zuni woman. "We-Wha" is probably the best joke the American Indian ever played on men and women of trained minds. "We-Wha" proved to be a man, and the father of four children!... (my emphasis) (Indian Truth, in Roscoe, Zuni ManWoman, 191).

It is clear that We-Wha was making fun of the "trained minds" of the West, represented by the most rational among them, i.e. the scientists. While they were eagerly escorting We-Wha from one place to another in Washington D.C., I imagine We-Wha thinking wittily how the West could be easily deceived by an indigenous person and a berdache, regarded as an amalgam of corruptness and abomination by Western people.

The fact that We'wha constantly taught Stevenson about the language, myths, and arts of the Zuni also testifies to his realization for the project of indigenizing, i.e. the idea that indigenous culture needs to be brought to the center of attention of the dominant society. Linda T. Smith defines indigenizing as "a centring of the landscapes, images, languages, themes, metaphors and stories in the indigenous world and the disconnecting of the many of the cultural ties between the settler society and its metropolitan homeland" (148). We'wha was keen on showing that the Zuni culture deserved serious attention from the dominant society since there was a lot that it could offer to other people and communities who would appreciate it. By meeting the national leaders and important figures in American society, We'wha brought indigeneity to the center so that the public could appreciate the value of indigenous culture. His choice to perform the native dance of the Zunis at his utmost ability was another piece of evidence of his awareness to bring indigenous culture to the central venue of the dominant society. 


\section{CONCLUSION}

The figure of We'wha demonstrates the ability of an indigenous Two-Spirit person to strategically play between the different areas of sexuality, gender identity, art, and labor. By crossing borders, Two-Spirit people manage to create an epistemological crisis in the Western world as We'wha constantly slipped the efforts of definition and categorization of the Other. The hegemony of gender binarism is made chaotic when gender identity cannot be defined since colonialism is founded on the carefully guarded separation between two opposite things. The existence of in-between gender identity creates confusion which the West can never solve. In this way, We'wha, a Zuni Two-Spirit person, was already engaged in the process of decolonization, in a time when American imperialism was just in the early phase. His success at disrupting the balance of Western epistemology may become an inspiration for indigenous people in the present era and in the future to respond to colonial regimes that have colonized indigenous communities for hundreds of years. We'wha has shown us that strategies of decolonization are certainly diverse, and they may appear and be enacted in the most unexpected, unpredictable forms.

\section{WORKS CITED}

Benedict, Ruth. Patterns of Culture. Boston: Houghton Mifflin, 1959, in Will Roscoe, The Zuni Man-Woman. Albuquerque: New Mexico U.P. 1991.

Callender, Charles and Lee M. Kochems. "The North American Berdache." Current Anthropology 24: 4, 1983. pp. 443-470.

Forgey, Donald G. "The Institution of Berdache Among the North American Plains Indians." The Journal of Sex Research 11: 1, 1975. pp. 1-15.

Hultkrantz, Ake. Shamanic Healing and Ritual Drama. New York: Crossroad. 1992.

Indian Truth (2(2):2-3, IC, IRAP, in Will Roscoe, The Zuni Man-Woman. Albuquerque: New Mexico U.P. 1991.

Parsons, Elsie Clews. “The Zuni La'mana.” American Anthropologist 18. 1916. pp. 521528.

Prior, Deborah. "Decolonizing Research: A Shift Toward Reconciliation," Nursing Inquiry 14, Brisbane: Blackwell. 2007. pp. 162-168.

Roscoe, Will. "'That is My Road': The Life and Times of a Crow Berdache." Montana: The Magazine of Western History 40: 1. 1990. pp. 46-55.

---. The Zuni Man-Woman. Albuquerque: New Mexico U.P. 1991.

---. "We' wha and Klah, The American Berdache as Artist and Priest." American Indian Quarterly 12:2, 1998. pp.127-150.

Sharp, Joanne. Geographies of Postcolonialism. California: Sage. 2009. 
Smith, Linda T. Decolonizing Methodologies, Research and Indigenous Peoples. New York: Zed Books Ltd. 2008.

Wilson, Alex. "How We Find Ourselves: Identity Development and Two-Spirit People." Harvard Educational Review 66: 2. 1996. pp. 303-317.

Wilson, Edmund. Red, Black, Blond and Olive, 20; Dissette to Willard, 3 March 1924, IC, IRAP, in Will Roscoe, The Zuni Man-Woman. Albuquerque: New Mexico U.P. 1991. 